\title{
Evaluation of avocado (Persea americana Mill.) leaves in terms of public health
}

\author{
Gülsen KENDİR 1 ${ }^{*}$, Ayşegül KÖROĞLU ${ }^{2}$ \\ 1 İstinye University, Faculty of Pharmacy, Department of Pharmaceutical Botany, 34010 Zeytinburnu, İstanbul, \\ Turkey. \\ 2 Ankara University, Faculty of Pharmacy, Department of Pharmaceutical Botany 06100, Tandoğan, Ankara, Turkey. \\ * Corresponding Author. E-mail: kendir08@gmail.com (G.K.); Tel. +9050584899 78; ORCID No: 0000-0001-8879- \\ 3751
}

Received: 14 November 2017 / Revised: 16 January 2018 / Accepted: 17 January 2018

\begin{abstract}
Persea americana Mill. (Lauraceae) originated in Central and Southern of South America, is an evergreen tree. The tree is commonly known as avocado. Avocado is cultivated in all tropical and subtropical regions in the world. This tree has been usually grown in the southern coastal region of Turkey due to its commercial importance. Its fruit is a drupe which consumed as food. Except this, the leaves are widely used for pass kidney stone and against the urinary tract infections as therapeutic among the people in Turkey and Cyprus.

The present study, 13 different samples from 5 diverse cities (Ankara, Hatay, İstanbul, Kayseri and Aydın) were purchased. The sample to be used as standard was obtained from the culture form (Dörtyol, Hatay). The morphological properties of leaves, which are part of the plant used as a drug, were determined both in the standard sample and in the purchased samples. Anatomical features of cross and surface sections from standard avocado leaves with cross sections from the petiole of natural avocado leaves were investigated and determined. Besides, the distinctive anatomical structures of the powdered samples (standard sample and samples purchased from the market) were demonstrated. The avocado leaf is bifacial. The hairs are only located the lower surface of the leaf and mostly unicellular. Secretory cells and crytals were observed in the avocado leaf and petiole. Crystals are simple in various sizes and small raphids. The stomata confined to the lower surface and anomocytic type (3-6 subsidiary cells). In cross section taken from the petiole, the hairs were observed to be gathered on the upper surface of the petiole.
\end{abstract}

KEYWORDS: Persea americana; Lauraceae; morphology; anatomy; powder drug; public health; traditional use.

\section{INTRODUCTION}

The genus Persea Mill. includes about 150 species of tropical evergreen trees. Persea name has been came from ancient Greek name of an Egyptian tree with sweet fruits originated propably from Perseus. Persea americana Mill. (Lauraceae) originated in Central and Southern of South America, is a shiny evergreen tree, known as "avocado". P. americana is a medium to large tree (9-20 $\mathrm{m}$ in height), much more branched, vigorous and round topped [1,2]. Avocado is cultivated in all tropical and subtropical regions in the world for its delicious and highly nutritious fruit. The leaves are $6-30 \mathrm{~cm}$ in length and $3.5-19 \mathrm{~cm}$ in wide and narrow to broadly elliptical in shape. They are constantly pubescent and reddish when young. When they mature, becoming smooth, leathery and dark green. Its fruit is consumed as food. P. americana is cultured in the southern coastal region of Turkey due to its commercial importance. The leaves are widely used for pass kidney stone and against the urinary tract infections as therapeutic among the people in Turkey [1, 3-6]. Besides these, they have been used internally as an infusion for diarrhea, stomachache, body pain, headache, wounds, fever, heart attack, osteoporosis, vomit, sore throat, to keep away from bad spirits in Mexico and as a decoction for high blood pressure in Caribbean islands $[7,8]$. The fresh leaves have been consumed in the form of aqueous infusion or decoction for influenza, bronchitis, menstruation pain, diabetes, rheumatism and also externally hair tonic in Ecuador and as well as the leaves have been employed as antimalarial in Nigeria $[9,10]$.

Especially, essential oils and flavonoids were reported to be present in P. americana leaf [11-15]. Also, avocado leaves contain persin which is a toxin for lactating livestock [16]. In vitro activity studies such as

How to cite this article: Kendir G, Köroğlu A. Evaluation of avocado (Persea americana Mill.) leaves in terms of public health. Marmara Pharm J. 2018; 22 (3): 347-356. 
anticancer, anticholinesterase, antimicrobial, antioxidant, antityrosinase have been performed on the leaves $[11,14,17-23]$. P. americana leaf has exhibited pharmacological activities such as analgesic, anti-inflammatory, anticonvulsant, antihyperlipidemic, hypocholesterolemic, hypoglycemic, hypotensive properties [24-28].

In this study, samples from different cities of Turkey sold with the name of "avokado yaprağı" in the market were taken and their morphological characteristics, anatomical structures and purities were investigated compared to the standard sample.

\section{RESULTS}

\subsection{The usage and sold}

It was determined that the samples sold in the market under the name of "avokado yaprağı" were generally sold in open conditions (Aydın, Hatay, İstanbul, Kayseri, Nicosia), but they were mostly sold in packages on Ankara. It has been determined that the drug are used as decoction for kidney and urinary tract inflammation, bile and kidney stones and edema in the direction of findings obtained from the public. Also, it has been observed that the drug are used as diuretic in Cyprus. Findings related to the use of the drug were found to be consistent with the source data [6-10].

\subsection{Morphological Results}

The leaves are simple, petiolate, elliptical to lanceolate, green, often pubescent, about $9-16.5 \mathrm{~cm}$ in lenght and $4.5-9 \mathrm{~cm}$ in width. The margin is entire. The lower surface is paler than the upper surface and midrib and veins more prominent below. The apex is usually acute, rarely acuminate; the base is usually acute with pinnate reticulate venation (Figure 1C, D). Findings obtained this study have found to be consistent with the data sources $[1,29]$. Morphological findings obtained from the examined samples which are given in Table 1 and Figures 2, 7. It was observed that the samples were generally composed of pure leaves, and fragmented. Mouldy and insect infested leaf samples were found in some samples (Figures 2B, 7A2, 7A3, 7C2, 7D2, 7E2). However, with not being too high, parts of other plants and foreign matter (stone and nylon pieces, etc.) were also identified as impurities (Figures 2A, 7).

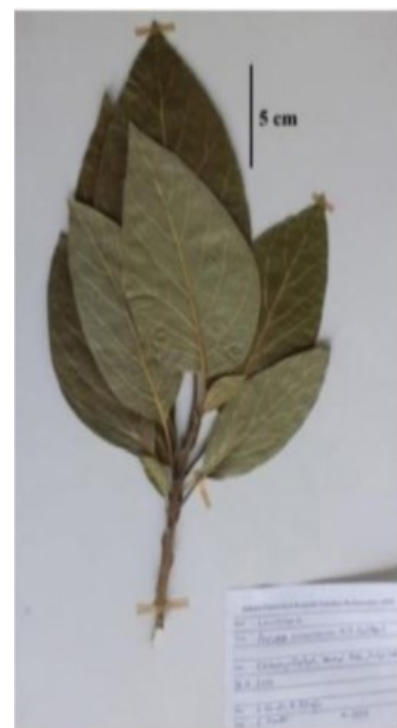

A

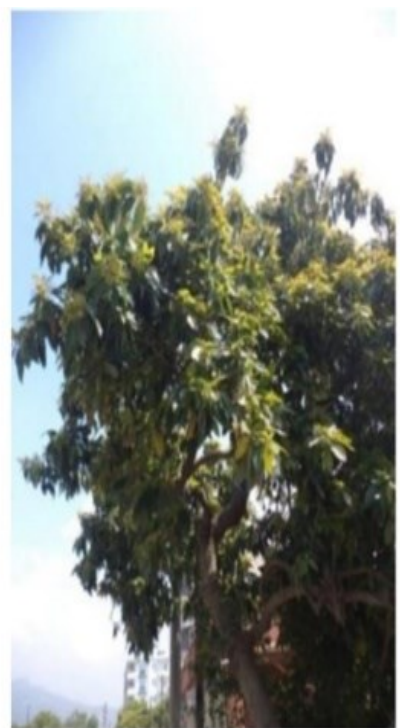

B

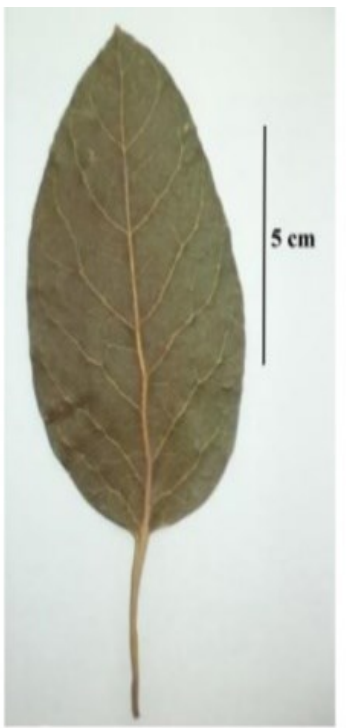

C

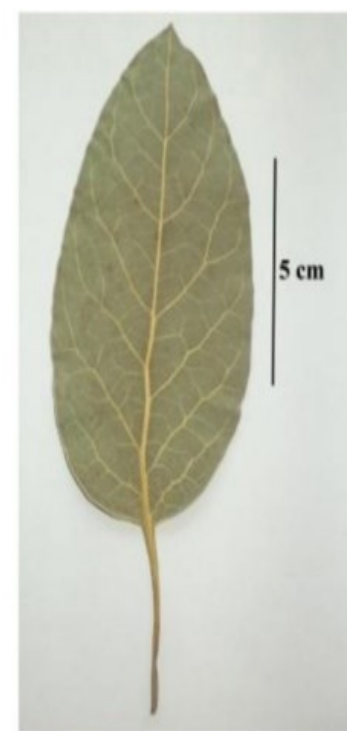

D

Figure 1. Persea americana A. Herbarium sample, B. Cultivated sample, C. Leaf upper surface, D. Leaf lower surface. 
Table 1. The morphological characteristics of drug samples used in the study.

\begin{tabular}{|c|c|c|c|c|}
\hline Sample & General apperance & Color & Leaf shape & $\begin{array}{l}\text { Proportion of non-drugs } \\
\text { items }\end{array}$ \\
\hline A1 & $\begin{array}{l}\text { Generally obsolete and } \\
\text { fragmented leaves }\end{array}$ & $\begin{array}{l}\text { Green, } \\
\text { brownish }\end{array}$ & Undetectable & $\begin{array}{l}1 \% \text { branch pieces, } 1 \% \\
\text { foreign matter (stone) }\end{array}$ \\
\hline A2 & $\begin{array}{l}\text { Generally fresh and } \\
\text { fragmented leaves but } \\
\text { obsolete and mouldy } \\
\text { leaves available }\end{array}$ & $\begin{array}{l}\text { Green, } \\
\text { brownish }\end{array}$ & Undetectable & $1 \%$ branch pieces \\
\hline A3 & $\begin{array}{l}\text { Generally fresh and } \\
\text { fragmented leaves but } \\
\text { obsolete and mouldy } \\
\text { leaves available }\end{array}$ & $\begin{array}{l}\text { Green, } \\
\text { brownish }\end{array}$ & Undetectable & $\begin{array}{l}1 \% \text { branch pieces, } 1 \% \\
\text { other plants parts }\end{array}$ \\
\hline AY & Generally fresh leaves & Green & Elliptical & - \\
\hline D1 & $\begin{array}{l}\text { Generally fresh and } \\
\text { fragmented leaves }\end{array}$ & Green & Undetectable & - \\
\hline D2 & $\begin{array}{l}\text { Generally fresh and } \\
\text { fragmented leaves, there } \\
\text { are also leaves eaten by } \\
\text { insects }\end{array}$ & Green & Undetectable & $1 \%$ branch pieces \\
\hline D3 & $\begin{array}{l}\text { Generally obsolete and } \\
\text { fragmented leaves }\end{array}$ & $\begin{array}{l}\text { Green, } \\
\text { brownish }\end{array}$ & Undetectable & $1 \%$ branch pieces \\
\hline I1 & $\begin{array}{l}\text { Generally fresh and } \\
\text { fragmented leaves }\end{array}$ & $\begin{array}{l}\text { Green, } \\
\text { brownish }\end{array}$ & Elliptical & $\begin{array}{l}1 \% \text { branch pieces, } 2 \% \\
\text { other plant parts }\end{array}$ \\
\hline I2 & $\begin{array}{l}\text { Generally fresh and } \\
\text { fragmented leaves, } \\
\text { mouldy leaves available }\end{array}$ & $\begin{array}{l}\text { Green, } \\
\text { brownish }\end{array}$ & Elliptical & - \\
\hline I3 & $\begin{array}{l}\text { Generally fresh and } \\
\text { shredded leaves }\end{array}$ & $\begin{array}{l}\text { Green, } \\
\text { brownish }\end{array}$ & Undetectable & $\begin{array}{l}1 \% \text { other plant parts, } 1 \% \\
\text { foreign matter (nylon } \\
\text { pieces) }\end{array}$ \\
\hline K1 & $\begin{array}{l}\text { Generally fresh and } \\
\text { fragmented leaves }\end{array}$ & Green & Undetectable & $1 \%$ branch pieces \\
\hline K2 & $\begin{array}{l}\text { Generally fresh and } \\
\text { fragmented leaves, there } \\
\text { are infested leaves by } \\
\text { insect }\end{array}$ & Green & Elliptical & $1 \%$ branch pieces \\
\hline K3 & $\begin{array}{l}\text { Generally fresh and } \\
\text { fragmented leaves }\end{array}$ & $\begin{array}{l}\text { Green, } \\
\text { brownish }\end{array}$ & Elliptical & $\begin{array}{l}1 \% \text { branch pieces, } 1 \% \\
\text { other plant parts , } 1 \% \\
\text { foreign matter (nylon } \\
\text { pieces) }\end{array}$ \\
\hline
\end{tabular}


A
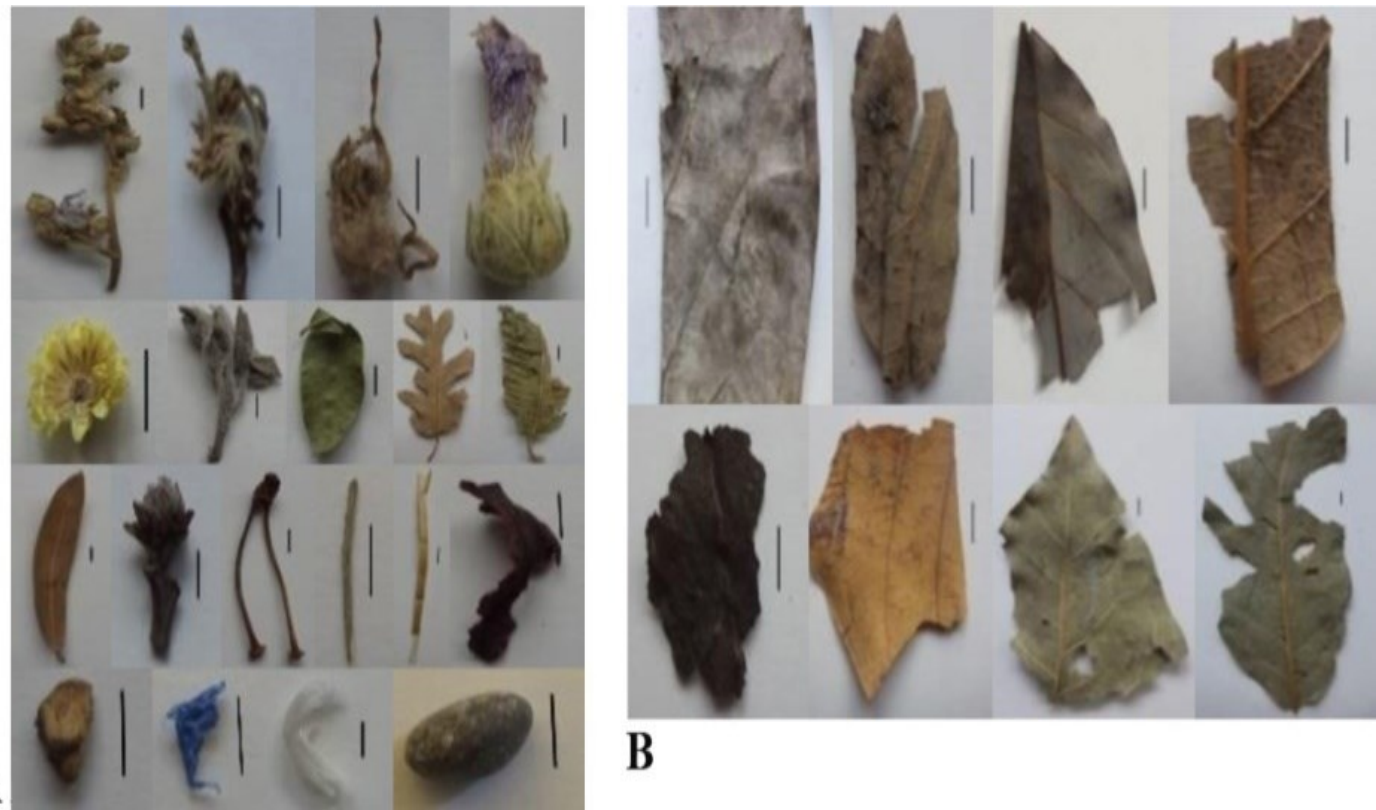

B

Figure 2. A. Parts of other plants and foreign matter observed in drug samples (scale $5 \mathrm{~mm}$ ), B. Mouldy and insect infested leaf samples (scale $5 \mathrm{~mm}$ ).

\subsection{Anatomical Results}

\subsubsection{Cross section of the leaf midrib}

Leaf is hypostomatic and bifacial. The upper and lower epidermis are uniseriate and the lower epidermal cells are larger and bigger than the upper epidermal cells, covered by a thick cuticle. The lower epidermis cells have beaded walls (Figures 3A, 3B, 3C). Palisade parenchyma, 1-2 layered, cells are long cylindrical. Spongy parenchyma with large intercellular spaces is located under the palisades. A few layers of collenchyma and colourless parenchyma cells are located beneath in the epidermis in the midrib region, and palisade and sponge parenchyma are not visible in this region. The vascular bundle is composed of the phloem on the outside and the xylem on the inside, and surrounded by a sclerenchymatous sheath. The covering trichomes are simple, mostly unicellular and thick walled. Secretory cells containing oil, and crystals in various sizes, small raphids and abundant starch were observed in especially parenchymatic cells (in the midrib region) (Figure 3).

\subsubsection{Surface section of the leaf upper epidermis}

The upper epidermis is composed of irregularly shaped cells with weightlessly sinuous walls. Below each epidermal cell, palisade parenchyma cell with a generally rounded shape ranging from 2 to 10 was seen. The hairs were not observed (Figure 4A).

\subsubsection{Surface section of the leaf lower epidermis}

The lower epidermis consists of irregularly shaped cells with significant sinuous walls. Stomata are anomocytic with 3-6 subsidiary cells. The simple, unicellular covering trichomes were found intensely (Figure $4 \mathrm{~B})$.

\subsubsection{Cross section of the petiole}

Epidermal cells are generally rectangular in a single layer with covered thick cuticle layer. Under the epidermal cells, there are multi-layers of collenchyma. The vascular bundle is located within parenchyma cells under collenchyma. Around the xylem and phloem is surrounded by a crescent-shaped of sclerenchymatous bundle. The covering trichomes, unicellular with thick walled, were determined to be collected especially on the upper surface of the petiole. Oil cells, abundantly crytals in various sizes, small raphids and starch were determined (Figure 5). 


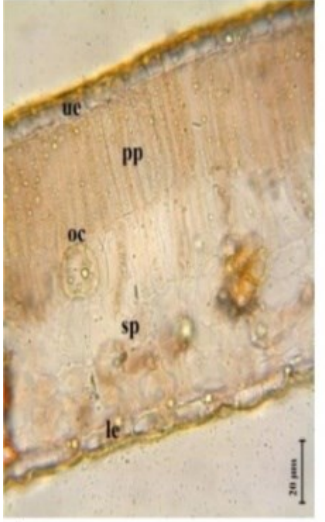

A

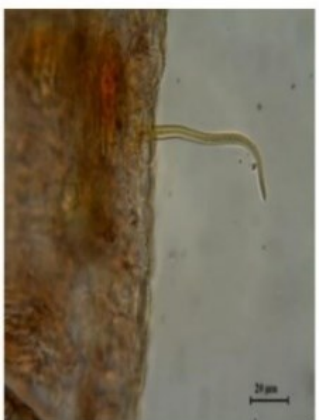

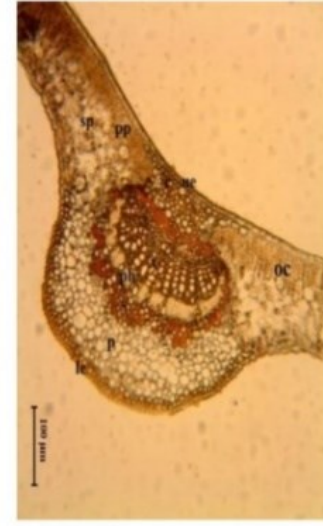

B

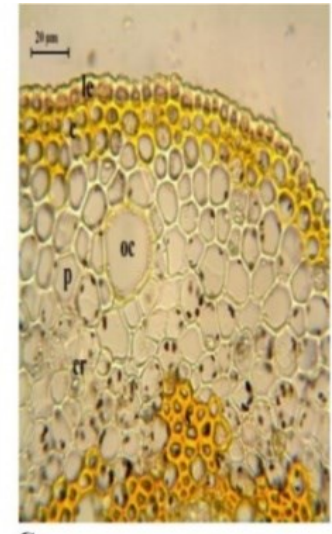

C

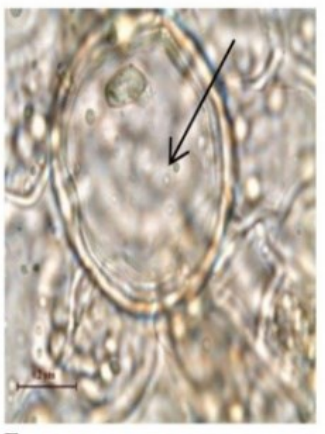

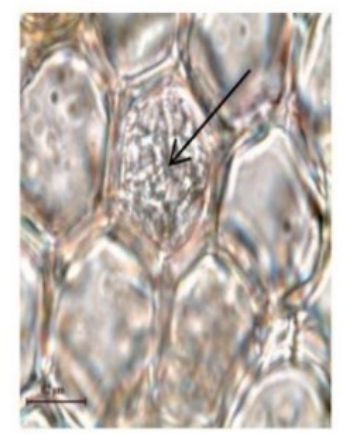

G

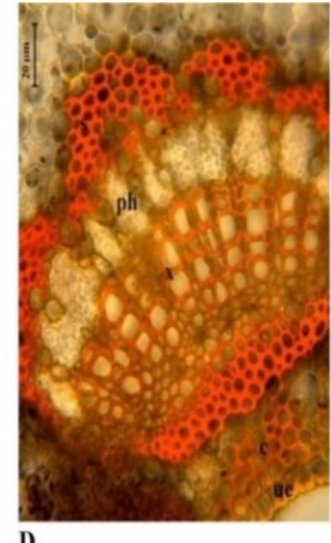

D

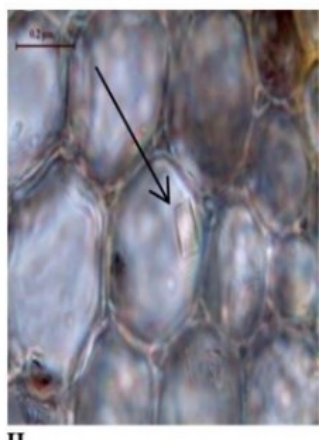

H

Figure 3. Cross section of leaf midrib of Persea americana A. Cross section of leaf blade, B. Leaf midrib and leaf blade, C. Leaf midrib, D. Vascular bundle, E. Covering trichome, F. Oil cell, G. Crystals in shape of small needles, H. Prismatic crystal.

ue: upper epidermis, le: lower epidermis, c: collenchyma, p: parenchyma, pp: palisade parenchyma, sp: spongy parenchyma, ph: phloem, x: xylem, s: sclerenchyma, cr: crystal, oc: oil cell.

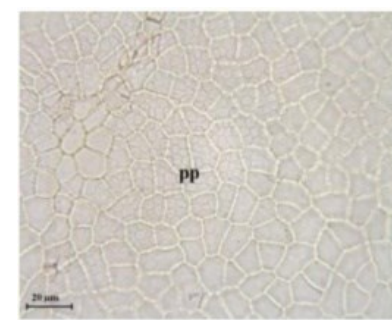

A1

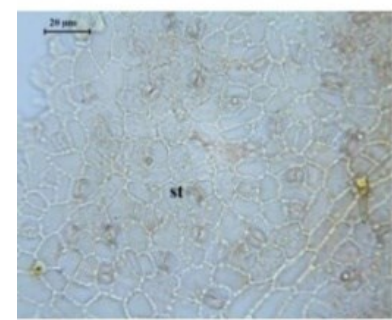

B1

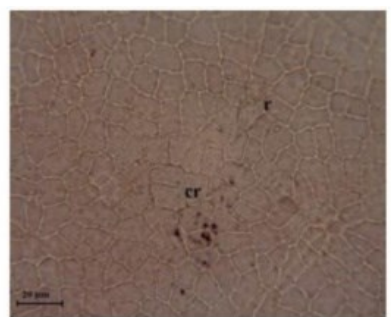

A2

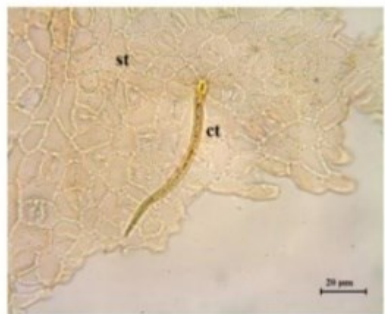

B2

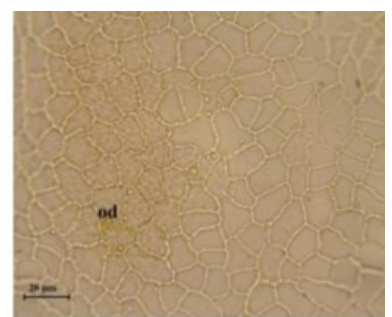

A3

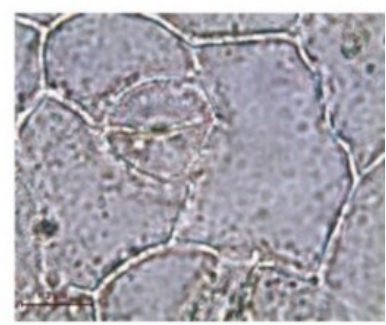

B3

Figure 4. A. Surface section of leaf upper epidermis of $P$. americana (A1. Upper epidermis and palisade parenchyma, A2. Upper epidermis, crystals and raphids, A3. Upper epidermis and oil drops), B. Surface section of leaf lower epidermis of P. americana (B1. Lower epidermis and stoma, B2. Lower epidermis and covering trichome, B3. Stoma). pp: palisade parenchyma, cr: crystal, r: raphids, od:oil drops, st: stoma, ct: covering trichome. 


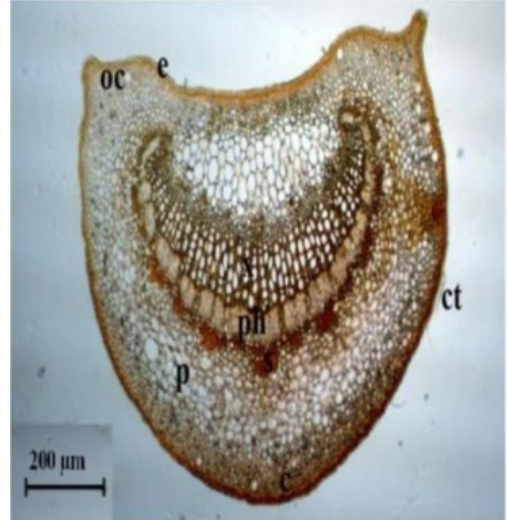

A

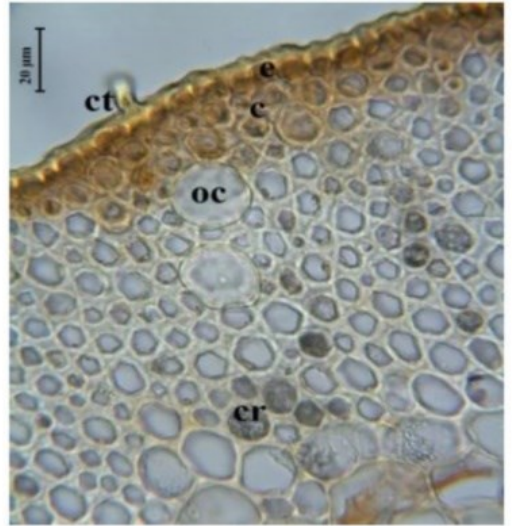

B

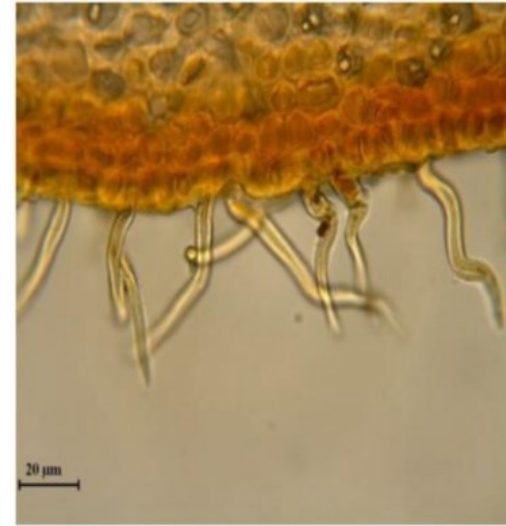

C

Figure 5. Cross section of the petiole of P. americana A. General view, B. Collenchyma, oil cells and crystals, C. Covering trichomes.

e: epiderma, c: collenchyma, ph: phloem, x: xylem, s: sclerenchyma, p: parenchyma, cr: crystal, oc: oil cell, ct: covering trichome.

\subsubsection{Examination of the powdered drug}

It was determined that all of the examined powdered drugs are fibrous, heterogeneous, in dark green colour. All samples were found to have an anise-like odour and a spicy taste. Also, the characteristic anatomical elements of samples were defined and illustrated in the Figure 6.

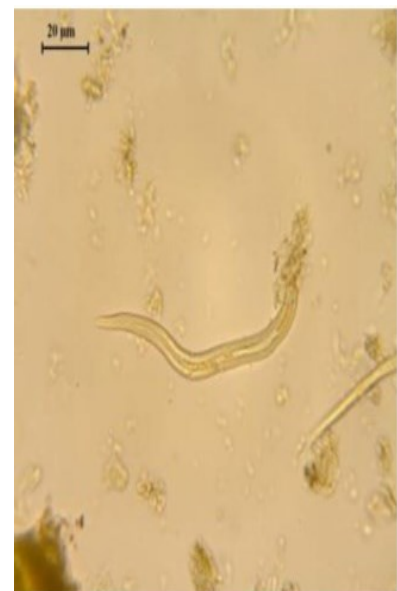

A

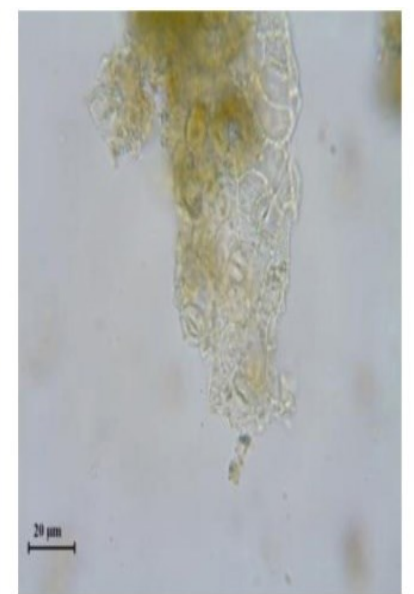

B

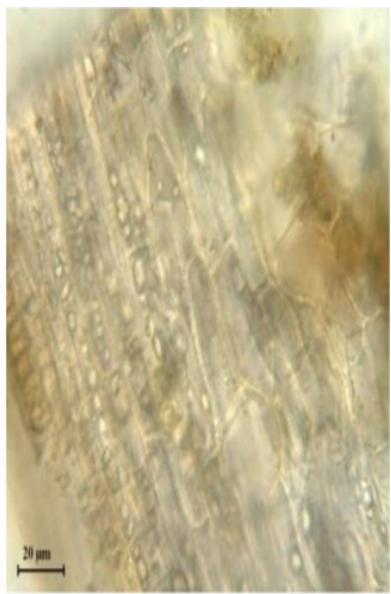

C

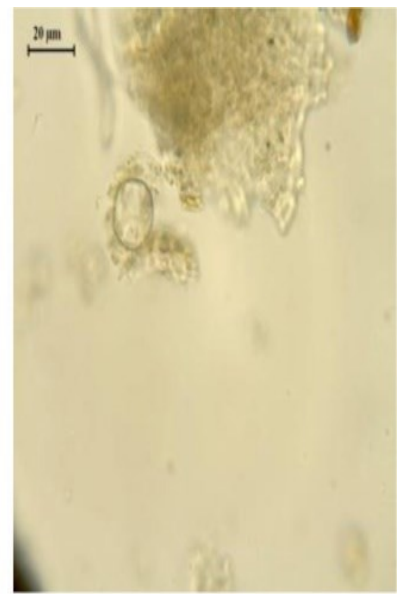

D

Figure 6. Microscopic properties of powdered drug samples of P. americana A. Covering trichome, B.

Stoma, C. Crystals, D. Oil cell.

\section{DISCUSSION}

This study was made to determine if they have scientific drug characteristics which used for its therapeutic feature in folk and supplied from the market of avocado leaves. The drug known as "avokado yaprağı" has been found to be usually sold as open. Morphological studies have shown that the samples are usually composed of pure leaves. Mouldy and insect infested leaf samples were found in the A2, A3, D2, I2 and K2 locations. AY, D1 and I2 locations are completely pure. The branches pieces of the plant were determined in almost all samples (1\%). Foreign matter presence in A1, I3 and K3 locations (stone and nylon pieces, etc.) was also determined. In addition to being not very high, the presence of other plants parts was also determined (Table 1). According to European Pharmacopoeia (2010) [30], herbal drugs should be free from moulds, insects and other animal contamination.

Anatomical examinations revealed the following findings: The leaf is bifacial. The covering trichomes, thick walled and mostly unicellular, are only located lower surface of the leaf, however, they are gathered partially on the upper surface of the petiole. Secretory cells, crytals in various sizes, small raphids were 
observed in the avocado leaf and petiole. The stomata occur only on lower epidermis of the leaf and anomocytic with 3-6 subsidiary cells (Figures 3-5). In addition, no different findings were observed in the powdered drug samples purchased from the market and standard sample. Obtained findings found to be generally consistent with the literature. Metcalfe and Chalk (1965) [31] reported cells of the lower epidermis were papillose and stomata were rubiaceous. Also, they mentioned the presence of hypoderm and mucilage cells in Persea. Mahmoud et al. (2016) [29] recorded thin cuticle layer and the presence of hairs on upper epidermis of the leaf. However, these anatomical features were not observed during the our anatomical examinations.

\section{CONCLUSION}

It has been determined that all of the samples presented to the sale are morphologically and anatomically formed from the correct drug, namely P. americana leaves. However, since the European pharmacopoeia [30] (2010) does not allow animal contaminations in herbal drugs, the samples do not carry the proper conditions for herbal drug description. In addition, the sales conditions of the samples were not considered suitable for human health.

\section{MATERIALS AND METHODS}

13 different samples were purchased from 5 different cities including İstanbul (3), Ankara (3), Kayseri (3), Hatay (3) and Aydin (1) and, standard sample was obtained from the culture form (AEF 26915) (Table 2). Information about use of the plant was received, but the sample was not purchased in Nicosia (North Cyprus). The morphological properties and purities of all samples were examined and photographed (Sony Cyber-shot DSC-S5000). In the anatomical study, cross and surface sections from standard avocado leaves with cross sections from the petiole were examined with Sartur reagent [32] under the microscope and the images on the light microscope were taken with a Leica DM 4000 B camera. Besides, the distinctive anatomical structures of the powdered samples (standard sample and purchased samples from the market) were demonstrated.

Table 2. The locations of the samples which used in the study.

\begin{tabular}{lcl}
\hline Location & Sample & Figure number \\
\hline Standard & $\begin{array}{c}\text { S } \\
\text { Cultured form from Dörtyol -Hatay } \\
\text { (AEF 26915) }\end{array}$ & Fig. 1 \\
\hline Ankara 1 & A1 & Fig. 2A1 \\
Ankara 2 & A2 & Fig. 2A2 \\
Ankara 3 & A3 & Fig. 2A3 \\
Aydın & AY & Fig. 2B \\
Dörtyol 1 (Hatay) & D1 & Fig. 2C1 \\
Dörtyol 2 (Hatay) & D2 & Fig. 2C2 \\
Dörtyol 3 (Hatay) & D3 & Fig. 2C3 \\
İstanbul 1 & I1 & Fig. 2D1 \\
İstanbul 2 & I2 & Fig. 2D2 \\
İstanbul 3 & I3 & Fig. 2D3 \\
Kayseri 1 & K1 & Fig. 2E1 \\
Kayseri 2 & K2 & Fig. 2E2 \\
Kayseri 3 & K3 & Fig. 2E3 \\
\hline
\end{tabular}




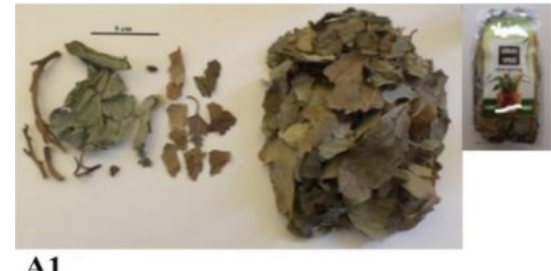

A1

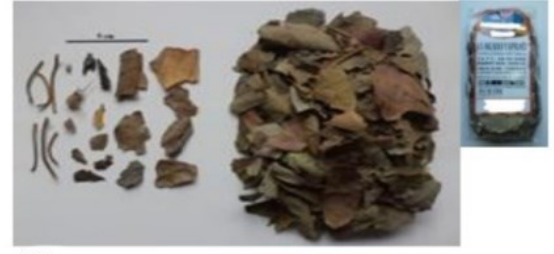

A2

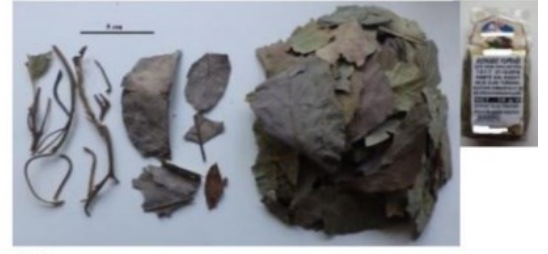

A3

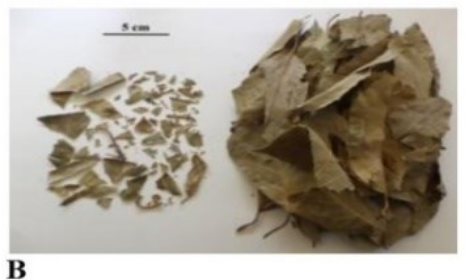

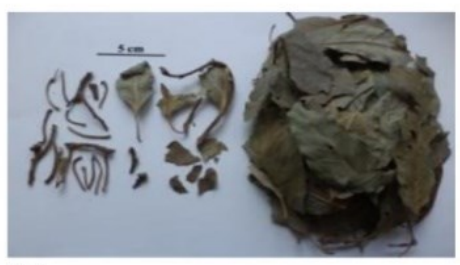

C2

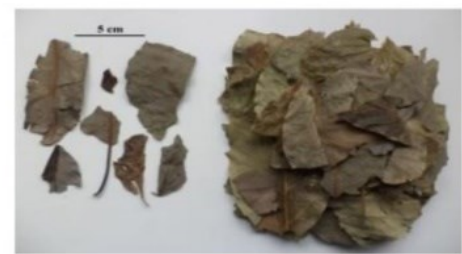

D2

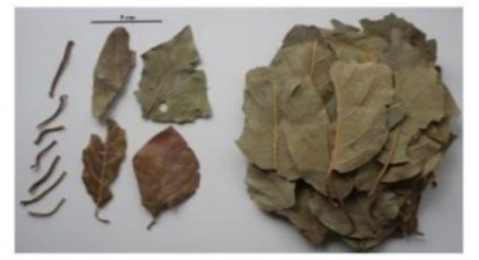

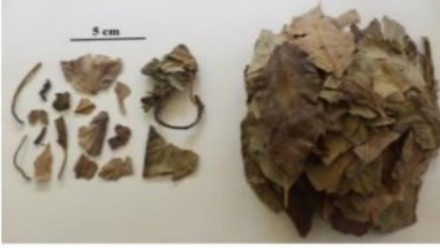

C3

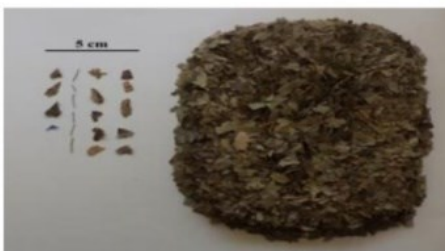

D3

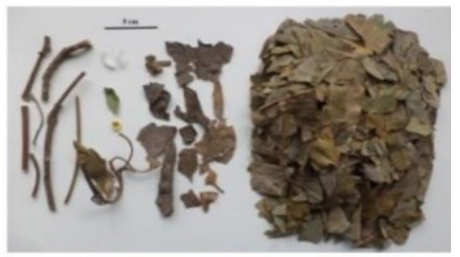

E3

Figure 7. A. Avocado samples obtained from markets in Ankara (A1. Sample 1, A2. Sample 2, A3. Sample 3), B. Avocado samples obtained from market in Aydın, C. Avocado samples obtained from markets in Hatay (C1. Sample 1, C2. Sample 2, C3. Sample 3), D. Avocado samples obtained from markets in İstanbul (D1. Sample 1, D2. Sample 2, D3. Sample 3), E. Avocado samples obtained from markets in Kayseri (E1. Sample 1, E2. Sample 2, E3. Sample 3).

Author contributions: Concept -A.K.; Design - A. K, G.K.; Supervision - G.K.; Resource - G.K.; Materials - G.K.; Data Collection and/or Processing - G.K.; Analysis and/or Interpretation - A.K., G.K.; Literature Search -G.K.; Writing G.K.; Critical Reviews - A.K., G.K.

Conflict of interest statement: The authors declared no conflict of interest.

\section{REFERENCES}

[1] Sharma G, Sharma OC, Thakur BS. Systematics of Fruit Crops. New India Publishing Agency, New Delhi, 2009.

[2] Yasir M, Das S, Kharya MD. The phytochemical and pharmacological profile of Persea americana Mill. Pharmacogn Rev. 2010; 4(7): 77-84.

[3] Demirkol A. Avocado growing in Turkey. Proceedings of the World Avocado Congress III. 1995: 451-456.

[4] Gruenwald J, Brendler T, Jaenicke C (Scientific Editors). Physicians Desk Reference (PDR) for Herbal Medicines. Thirth Edition, Thomson/Medical Economics Company, Montvale, New Jersey, 2004. 
[5] Bayram S. BATEM, 2010 Yılı Avokado Gelişim Raporu, 2010.

[6] Sargin SA. Ethnobotanical survey of medicinal plants in Bozyazi district of Mersin, Turkey. J Ethnopharmacol. 2015; 173: $105-126$.

[7] Josabad Alonso-Castro A, Jose Maldonado-Miranda J, Zarate-Martinez A, JacoboSalcedo MR, Fernández-Galicia C, Alejandro Figueroa-Zuñiga L, Abel Rios-Reyes N, Angel de León-Rubio M, Andrés Medellín-Castillo N, ReyesMunguia A, Méndez-Martínez R, Carranza-Alvarez C. Medicinal plants used in the Huasteca Potosina, México. J Ethnopharmacol. 2012; 143: 292-298.

[8] Clement YN, Baksh-Comeau YS, Seaforth CE. An ethnobotanical survey of medicinal plants in Trinidad. J Ethnobiol Ethnomed. 2015; 11: 67.

[9] Tene V, Malagón O, Finzi PV, Vidari G, Armijos C, Zaragoza T. An ethnobotanical survey of medicinal plants used in Loja and Zamora-Chinchipe, Ecuador. J Ethnopharmacol. 2007; 111: 63-81.

[10] Dike IP, Obembe OO, Adebiyi FE. Ethnobotanical survey for potential anti-malarial plants in south-western Nigeria. J Ethnopharmacol. 2012; 144(3): 618-626.

[11] De Almeida AP, Miranda MMFS, Simoni IC, Wigg MD, Lagrota MHC, Costa SS. Flavonol monoglycosides isolated from the antiviral fractions of Persea americana (Lauraceae) leaf infusion. Phytother Res. 1998; 12: 562-7.

[12] Ogunbinu AO, Ogunwandeb IA, Flaminid G, Cionid PL. Volatile compounds of Persea americana Mill from Nigeria. J Essent Oil Bear Pl. 2007; 10: 133-138.

[13] Larijani K, Rustaiyan A, Azar PA, Nematollahi F, Taban S. Composition of essential oil of leaves of Persea americana cultivated in Iran. Chem Nat Compd. 2010; 46: 489-490.

[14] Owolabi MA, Coker HAB, Jaja SI. Bioactivity of the phytoconstituents of the leaves of Persea americana. J Med Plants Res. 2010; 4: 1130-1135.

[15] Niogret J, Epsky ND, Schnell EQ, Schnell RJ, Heath RR, Meerow AW, Kendra PE. Analysis of sesquiterpene distributions in the leaves, branches, and trunks of avocado (Persea ameriana Mill.). Am J Plant Sci. 2013; 4: 922-931.

[16] Oelrichs PB, Ng JC, Seawright AA, Ward A, Schaffeler L, MacLeod JK. Isolation and identification of a compound from avocado (Persea americana) leaves which causes necrosis of the acinar epithelium of the lactating mammary gland and the myocardium. Nat Toxins. 1995; 3: 344-349.

[17] Miranda MMFS, Almeida AP, Costa SS, Santos MGM, Lagrota MHC, Wigg MD. In vitro activity of extracts of Persea americana leaves on acyclovir-resistant and phosphonoacetic resistant herpes simplex virüs. Phytomedicine. 1997; 4(4): 347-352.

[18] Gomez-Flores R, Arzate-Quintana C, Quintanilla-Licea R, Tamez-Guerra P, Tamez-Guerra R, Monreal-Cuevas E, Rodríguez-Padilla C. Antimicrobial activity of Persea americana Mill (Lauraceae) (Avocado) and Gymnosperma glutinosum (Spreng.) Less (Asteraceae) leaf extracts and active fractions against Mycobacterium tuberculosis. AmericanEurasian Journal of Scientific Research (AEJSR). 2008; 3(2): 188-194.

[19] Engel N, Oppermann C, Falodun A, Kragl U. Proliferative effects of five traditional Nigerian medicinal plant extracts on human breast and bone cancer cell lines. J Ethnopharmacol. 2011; 137: 1003-1010.

[20] Rosas-Pinón Y, Mejía A, Díaz-Ruiz G, Aguilar MS, Sánchez-Nieto S, RiveroCruz JF. Ethnobotanical survey and antibacterial activity of plants used in the Altiplane region of Mexico for the treatment of oral cavity infections. J Ethnopharmacol. 2012; 141: 860-865.

[21] Bonilla-Porras AR, Salazar-Ospina A, Jimenez-Del-Rio M, Pereañez-Jimenez A, Velez-Pardo C. Pro-apoptotic effect of Persea americana var. Hass (avocado) on Jurkat lymphoblastic leukemia cells. Pharm Biol. 2014; 52: 458-465.

[22] Oboh G, Odubanjo VO, Bello F, Ademosun AO, Oyeleye SI, Nwanna EE, Ademiluyi AO. Aqueous extracts of avocado pear (Persea americana Mill.) leaves and seeds exhibit anti-cholinesterases and antioxidant activities in vitro. J Basic Clin Physiol Pharmacol. 2016; 27: 131-140.

[23] Uysal S, Zengin G, Aktumsek A, Karatas S. Chemical and biological approaches on nine fruit tree leaves collected from the Mediterranean region of Turkey. J Funct Foods. 2016; 22: 518-532.

[24] Adeboye JO, Fajonyomi MO, Makinde JM, Taiwo OB. A preliminary study on the hypotensive activity of Persea americana leaf extracts in anaesthetized normotensive rats. Fitoterapia. 1999; 70: 15-20.

[25] Adeyemi OO, Okpo SO, Ogunti OO. Analgesic and antiinflammatory effects of the aqueous extract of leaves of Persea americana Mill (Lauraceae). Fitoterapia. 2002; 73: 375-380. 
[26] Ojewole JA, Amabeoku GJ. Anticonvulsant effect of Persea americana Mill (Lauraceae) (Avocado) leaf aqueous extract in mice. Phytother Res. 2006; 20: 696-700.

[27] Brai BIC, Odetola AA, Agomo PU. Hypoglycemic and hypocholesterolemic potential of Persea americana leaf extracts. J Med Food. 2007; 10: 356-360.

[28] Kolawole OT, Kolawole SO, Ayankunle AA, Olaniran IO. Methanol leaf extract of Persea americana protects rats against cholesterol-induced hyperlipidemia. Br J Med Med Res. 2012; 2(2): 235-242.

[29] Mahmoud AH, Samy MN, Wanas AS, Kamel MS. Pharmacognostical investigation of leaf and stem of Persea americana. Int J Pharmacogn Phytochem Res. 2016; 8(4): 690-700.

[30] European Pharmacopoeia, 7th edition. Volume 1. Strasbourg: Council of Europe, 2010.

[31] Metcalfe CR, Chalk L. Anatomy of Dicotyledones. Vol. 2, Clarendon Press, Oxford, 1965.

[32] Çelebioğlu S, Baytop T. Bitkisel tozların tetkiki için yeni bir reaktif. Farmakognozi Enstitüsü Yayınları, No. 10. Farmakolog 19: 301, 1949.

This is an open access article which is publicly available on our journal's website under Institutional Repository at http://dspace.marmara.edu.tr. 